\title{
INNOVATION PROFILE FROM THE PERSPECTIVE OF TECHNOLOGY ROADMAPPING PRACTITIONERS IN SOUTH AFRICA
}

\author{
T.P. Letaba ${ }^{1,2 * \#}$, M.W. Pretorius ${ }^{2} \&$ L. Pretorius ${ }^{2}$
}

\section{ARTICLE INFO}

Article details

Submitted by authors 10 Feb 2018

Accepted for publication 3 Nov 2018

Available online $\quad 10$ Dec 2018

\section{Contact details}

Corresponding author

petrus.letaba@dst.gov.za

Author affiliations

1 National Advisory Council on Innovation, South Africa

2 Graduate School of Technology Management, University of Pretoria, South Africa

\# The author was enrolled for a PhD (Technology Management) degree in the Graduate School of Technology Management, University of Pretoria, South Africa

\section{DOI}

http://dx.doi.org/10.7166/29-4-1919
ABSTRACT

The objective of this paper is to derive the innovation profile in developing countries, such as South Africa, from a technology roadmapping practitioner's point of view. The specific research questions that are addressed are i) what are the main priorities for innovation in South Africa? and ii) what are the actual or perceived innovation competitive advantages for South Africa? A mixed methodology research is used that combines online quantitative surveys, qualitative interviews, and document analysis. The quantitative survey was conducted with researchers and practitioners involved with technology roadmaps in South Africa. Through the realism research philosophy that combines both inductive and deductive approaches, an analytical inference is made through the five propositions that have managerial and policy implications for the technology roadmapping community in developing countries.

\section{OPSOMMING}

Die doel van hierdie artikel is om die innovasieprofiel wat in ontwikkelende lande soos Suid-Afrika in gebruik is, uit die oogpunt van 'n tegnologiepadkaartpraktisyn af te lei. Die spesifieke navorsingsvrae wat aangespreek word, is i) "Wat is die belangrikste prioriteite vir innovasie in Suid-Afrika?" en ii) "Wat is die werklike of waargenome innovasie mededingendheid voordele vir SuidAfrika? ' $n$ Gemengde metodologie-navorsing is gebruik wat aanlyn kwantitatieweopnames, kwalitatiewe onderhoude, en dokumentanalise kombineer. Die kwantitatiewe opname is uitgevoer met navorsers en praktisyns wat betrokke is by tegnologiepadkaarte in Suid-Afrika. Deur die realisme navorsingsfilosofie wat beide induktiewe en deduktiewe benaderings kombineer, is ' $n$ analitiese inferensie gemaak deur die vyf stellings wat bestuurs- en beleidsimplikasies vir die tegnologiepadkaart gemeenskap in ontwikkelende lande het.

\section{INTRODUCTION}

Most developing countries suffer from an underinvestment in research, technology, and innovation infrastructures. This is further exacerbated by the lack of an innovation and entrepreneurship culture, which results in short-term innovation planning. The technology roadmapping technique provides a long-term planning framework that integrates corporate and technology planning. This forward-looking strategic planning tool facilitates the collection and documentation of future technology expectations of what is likely to happen, but also combines this with the future desires of the key stakeholders and commitments from these stakeholders [1]. Technology roadmaps (TRMs) facilitate consensus between stakeholders, and represent the innovation dynamics taking place in the organisation, industry, or the country for which the roadmap is developed. Indeed, Phaal and Muller [2] view TRM as a general-purpose 'strategic lens' through which a complex innovation system 
can be viewed through well-structured and well-represented multiple interrelated perspectives: commercial and strategic perspectives; design, development, and production perspectives; and technology and research perspectives. The most common graphical format of TRM shows a visual representation of the innovation dynamics through multi-layered horizontal graphs that show time horizons on the vertical axis and a set of themes on the vertical axis [3].

The objective of this paper is to derive the innovation profile of developing countries, such as South Africa, from a technology roadmapping practitioner's point of view. The specific research questions that are addressed are i) what are the main priorities for innovation in South Africa? and ii) what are the actual or perceived innovation competitive advantages for South Africa? The national system of innovation practitioners has raised concerns about the lack of research, technology, and innovation prioritisation in South Africa [4]. And with the diversity of innovation competencies in South Africa, there is also no consensus on a set of key competitive advantages for the country.

A multi-level perspective of a complex innovation system is used as the analytical framework to structure these dynamics at the macro-, meso-, and micro-levels. This framework allows for the differentiation of various role players in the innovation landscape (government policy, economy, society, etc.), innovation regime (incumbents, industry associations and/or large companies), and niche innovators. As discussed by Pretorius [5], once two or more competing technologies are diffused into the market, they can be evaluated as a technology system using a systems dynamics approach. Hence the use of a complex systems theory as a basis for the analytical framework.

This paper is structured as follows: a brief literature review on knowledge domains, such as innovation linkages and networks (section 2 ) and technology management in developing countries (section 3); section 4 describes the methodologies adopted for the collection of data; while section 5 presents the results and an in-depth analysis. Several analytical propositions are generated. The concluding section puts forward possible managerial and policy implications.

\section{INNOVATION LINKAGES AND NETWORKS}

Innovation is a complex activity that takes place within a sophisticated ecosystem of idea generators, innovators, product/process developers, marketers, organisational development functions, etc. The innovation ecosystem involves dynamic and nonlinear linkages among these actors. In fact, most successful innovations do not take place in isolation, but entail tracking your partners and potential adopters as closely as you track your own development process [6]. The innovation linkages may be formal, through collaboration agreements; or they may be informal, through spontaneous collaborations [7]. Various models exist to describe these linkages: national systems of innovation (NSI), the triple helix model, the knowledge triangle, the innovation cluster, open innovation, etc.

An NSI concept in relation to firm-level innovation is centred on internal firm dynamics, including innovation management and competitive strategies; firm size; interaction between firms, suppliers, and markets; and technology and information transfer mechanisms [8]. A national innovation system depends mainly on the government's national policy [9] on issues such as competition and macroeconomics. It also depends on the behaviour of national institutions such as agencies funding the basic research, technology development, and commercialisation; banks and stock markets; systems of corporate governance; and so on.

The innovation cluster model is related to the concept of the national innovation system, but is more at the regional level. Silicon Valley is the most famous high-technology innovation cluster: it has inspired the development of similar clusters in other countries. The Ottawa high-technology cluster, also known as Silicon Valley North, is an example of such a cluster. Some factors that were crucial in its development are: i) access to technology and technical know-how, ii) availability of highly qualified people, iii) visionary entrepreneurship, iv) access to venture capital, and v) networks and linkages [10].

In this era of the fourth industrial revolution, open innovation is a useful model that facilitates innovation linkages. The benefits of the open innovation paradigm were highlighted by the previous failure of firms to gain commercial value from their successfully developed technologies. For example, although Xerox's 30 year investment in research and technology through its Palo Alto Research Centre (PARC) yielded advanced technologies such as GUI and the Ethernet networking 
protocol, society benefited more from these efforts than Xerox itself [11]. This is attributed to a paradigm of closed innovation that was dominant at that time. According to the author, most Xerox technologies were successfully converted to economic value when key PARC researchers left Xerox for smaller companies or, alternatively, when they created their own companies. The open innovation model is therefore useful for individual organisations to benefit from other complementary innovations in order efficiently to create value out of technologies they have developed.

The triple helix model - linking industry, universities, and government - is premised on a dynamic relationship that involves the economic dynamics of the market, the internal dynamics of knowledge production, and governance of the interface at different levels [12]. Various triple helix models exist; the most famous are university-pushed, government-pulled, and industry-led innovation models. An industry-led triple helix model is prominent in some advanced countries, such as Turkey [13]. The university-pushed innovation model, which is prevalent in the USA, involves highly entrepreneurial universities that collaborate with other actors to advance regional innovation [14]. The government-pulled triple helix innovation model, which is prevalent in China, is centred on the government acting as a leader of other partners, rather than as a 'collaborative partner' within a triple helix network [15]. Such leadership takes place through initiatives such as China's 15-year 'Medium-to-Long-Term Plan for the Development of Science and Technology', and by supplementing the universities' novelty creation function with that of state research institutions.

Most developing countries, such as South Africa, have adopted this government-pulled model. Of South Africa's 25 universities, only about one sixth are research universities, while the rest of them are predominantly teaching universities. In addition to the top five research-intensive universities, most of the research is conducted by science councils such as the Council for Scientific and Industrial Research (CSIR), the Agricultural Research Council (ARC), the Medical Research Council (MRC), MINTEK, etc. A recently developed knowledge triangle model provides an analytical framework for consolidating a government-led innovation model that is concerned with a greater integration of the education, research, and innovation activities of higher education institutions (HEls) and public research institutions (PRIs) in order to enhance their impact on innovation and economic growth [16].

\section{TECHNOLOGY MANAGEMENT IN DEVELOPING COUNTRIES}

In a context of increasing globalisation and integrated global trade, the global value-chain literature is an ideal starting point to analyse technology management in developing countries. The innovation capacity development theory by design is intertwined with global value-chain upgrading theories. For developing countries, social and organisational innovations are worth exploring due to various societal and institutional challenges faced by these countries.

\subsection{Innovation management within a global value chain}

Developing countries are known to be net importers of technology and high-technology products in terms of trade balance. A well-known, persistent, and sticky challenge is the low levels of productivity [17] that accompany high production costs, lack of key skills, and lack of access to capital [18]. According to Bartelsman and Doms [18], aggregate productivity at a firm level is influenced by the factors that can be controlled not only by a firm (innovation activity, input choices, and outputs), but also by market interactions, such as the type of competition and market share.

Within the scope of technology roadmapping, these competitiveness challenges faced by developing countries are analysed through the use of a value-chain framework and the literature relating to the upgrading of the value delivery system. Kaplinsky and Morris [19] define 'value chain' as the full range of activities that are required to bring a product or a service from conception, through the different phases of production, to delivery to consumers, and disposal.

In the value-chain literature, the global value-chain analysis that studies power relationships and information asymmetry between lead firms and other firms, such as those in developing countries [20], partially explains the productivity challenges and cost drivers that hamper innovation in developing countries. An important issue of significance is a concept of value-chain governance, which is based on the fact that few lead firms in the global value chain set or enforce the parameters within which others in the chain operate [21]. According to the authors, some value chain aspects 
that are controlled by these lead suppliers are market access, fast-tracking of production capabilities acquisition, support for host country policy initiatives, and technical assistance. Global value-chain governance has co-evolutionary characteristics due to continuous adjustments and changes [22].

Kaplinsky and Morris [19] view value chains as "repositories for rent which result from possession of scarce competitive resources and creation of the barriers to their access". These barriers create superficial scarcity, which results in super returns for innovations of lead firms. The economic rent is explained by Kaplinsky and Morris [19] as arising from the differential productivity of factors (including entrepreneurship) and barriers to entry (scarcity); as relational rents arising from purposeful activities taking place between groups of firms; and in terms of its various forms, such as technological capabilities, organisational capabilities, skills, and marketing capabilities. Royalties and licences on patents, franchises, trademarks, and industrial designs are all typical examples of economic rent.

According to Humpfrey and Schmitz [21], an increasing number of developing country producers engage in contract manufacturing, as brands play a key role in customers' purchase decisions. Increasing contract manufacturing trends result from the fact that success in technological innovation depends on consumer acceptance.

For firms in developing countries to overcome their challenges within the vicious cycle characterised by the lack of entrepreneurship, lack of innovation, lack of productivity, lack of skills, etc., they need to upgrade their participation in global innovation value chains to establish a new sustainable equilibrium. Various scholars have investigated mechanisms for value chain upgrade in developing countries $[21,23,24]$. Such frameworks for value chain upgrading, unfortunately, take the form of being compliant to the demanding technology, production, and product standards of the lead suppliers, rather than on developing countries' firms to be equal partners in the global value chain.

Humphrey and Schmitz [21] discuss four types of value chain upgrading: (i) process upgrading, (ii) product upgrading, (iii) functional upgrading, and (iv) intersectoral upgrading. Process upgrading involves the transformation of inputs to outputs more efficiently by reorganising the production system or by introducing a superior technology. Product upgrading entails a shift into more sophisticated product lines, whereas functional upgrading takes place when firms acquire new functions or abandon existing functions so that they increase the skill content of their activities. Lastly, intersectoral upgrading takes place when firms apply competencies acquired in a specific function of a value chain to move into a new sector.

Kaplinsky et al. [23] applied these four value chain upgrading trajectories to the global wood furniture value chain, an industry that is driven mainly by the buyers. This work focused on key initiatives that the producers in developing countries need to do in order to upgrade their activities. Some findings in this work include issues such as global buyers blocking producers within the footwear sector from moving into more profitable activities, such as design and branding. On the other hand, these global buyers fully support the growth of producers' manufacturing capability. According to Zamora [24], buyer-driven value chains are common in labour-intensive consumer goods industries, where large retailers, merchandisers, and trading companies play a central role in establishing production networks, especially within developing countries. Producer-driven value chains are characterised by capital-intensive and technologically oriented industries dominated by large multinational corporations (MNCs), which play a key role in managing the production networks [25].

Some industrial policies that can be useful to facilitate access to global value chains include decreasing the burden associated with the international transportation of goods, customs clearance, and distribution within the importing countries [23]. These policy interventions, according to the authors, should generally be aimed at reducing costs, delivery times, and uncertainty. According to Gereffi [26], a modern-day global value chain oriented industrial policy focuses to a greater extent on the intersection of global and local actors, and it takes the interests, power, and reach of lead firms and global suppliers into account, accepts international business networks as the appropriate field of play, and responds to pressures from international non-governmental organisations. 


\subsection{Innovation capacity development}

The global value chain literature highlights various issues of interest regarding the development of innovation capacity in developing countries. Through globalisation, the national innovation systems of different countries are interlinked, and it is almost impossible to think of such a system without considering the strong exogenous factors, such as international finance and trade, as having the greatest influence on the system. De Marchi, Giuliani and Rabellotti [27] observed that, in order to understand how firms involved in global value chains innovate, scholars should not focus entirely on global value chain characteristics and the role of lead firms; instead, they should take into account domestic technological capabilities at the firm level, the industrial cluster/regional level, and local innovation system levels. Buys [28] deduced from the innovation survey results that, in developing countries such as South Africa, most innovations are based on activities that are not related to research and development (R\&D) and that consist of operationalising technology that is new to the situation of application. Such activities can involve product or process adaptation aimed at converting the acquired technology to be in line with local market needs.

Some of the factors that hamper innovation and technological capability development in developing countries are low levels of educational attainment, a complex business environment, and an underdeveloped information infrastructure [29]. According to the author, during the pre-industrial phase the required educational level was basic literacy, whereas in the industrial phase more professional and medium-level skills are required. Some additional institutional barriers that affect innovation in developing countries are: (i) competition fairness, (ii) access to finance, (iii) laws and regulations, (iv) the tax burden, and (v) support systems [30].

There are various frameworks for innovation capacity development. For example, Kocoglu et al. [31] investigated factors that promote technological learning, with the main focus on complementary learning, manufacturing, and R\&D capabilities. These are thought of as a critical foundation for a systemic innovation strategy through the establishment of appropriate routines, accumulation of internal skills, and development of the ability to learn selectively. R\&D capabilities enable organisations to assimilate knowledge from external sources, but also for novel inventions [32]. The impact of existing manufacturing capability on technological innovation capacity can be explained in terms of a concept of technological distance. Krishanduth and Chan [33] concluded that a large technological distance has a negative effect on absorptive capacity, although this can have a positive effect on the potential for novelty creation.

In developing countries, technological learning can also be achieved through technology transfer from developed countries. Some of the mechanisms that exist to effect such technology transfer are foreign direct investment (FDI) and intellectual property exchange through trade in embodied and disembodied technologies. FDI has been instrumental in technology transfer from MNCs to developing countries in East Asian countries such as China [34]. On the other hand, South Korea chose to rely less on FDI, and instead encouraged domestic firms to build extensive global networks, with foreign firms providing technology via licensing, capital goods, and original equipment manufacturers' contracts [35]. East Asia's contradictory experience of the role of FDI in technology transfer from developed countries can be reconciled through the observation that, in either case, foreign technological know-how played a significant role in local technological capability development. Various policy frameworks can be used by governments in developing countries to accelerate technology transfer into their countries, ranging from economy-wide programmes (such as improved education levels), to funding for the creation and acquisition of technology, to tax incentives for the purchase of capital equipment, and to a favourable intellectual property rights regime [36].

In some instances, regulatory reforms become necessary in developing countries to enable technological innovation and to remove the obstacles that stifle innovation. Various forms of government regulations exist in areas such as the environment, safety, health, competition, intellectual property rights, land use, labour, etc. These regulations differ for every country, as they can be prescriptive or performance-based. Prescriptive regulations, which are more of the 'command and control' type, are shown to support incremental innovation [37]. For emerging technologies, therefore, deregulation or performance-based regulations are more favourable options - as shown in the case of Uber, a company that is increasingly becoming a poster-child for antiregulation [38]. It has been argued in the literature that innovation should precede regulation [39], with a typical exception being environmental technology innovations, which are typically nurtured 
by environmental regulations [40]. In some instances, escape clauses can be used within regulations to enable innovation through emerging technologies.

The philosophy adopted for this non-probabilistic research is a realism perspective, which combines both deductive and inductive approaches. An online quantitative survey was conducted with researchers and practitioners involved with TRMs in South Africa. The 44 responses received came from different sectors, such as the government, state-owned corporations, large companies, SMMEs, science councils, industry associations, higher education, etc. The choice of sample was stratified to represent the roadmapping community from various sectors. A major limitation experienced was access to, or even knowledge about, potential technology roadmapping activities in the private sector. This challenge of a 'hidden-population' [41] was mitigated through a web search, a literature search, and scanning of social media platforms such as Linkedln. However, the information contained on social media had to be validated and 'cleaned', as it might not always have been correct [42].

The semi-structured qualitative interviews were arranged with 13 selected senior managers for the follow-up questions. The aim of these interviews was to fill the gaps not addressed by the quantitative survey, and to obtain more analytical clarity on sociotechnical transitions, challenges, and strategies. These respondents incorporate actors from the innovation landscape, the innovation regime, and niche innovations.

Content analysis was also carried out on publicly available technology roadmapping documents in South Africa. The use of secondary data, in addition to primary data, is useful to triangulate the results and to ensure their validity. Both qualitative and secondary data are not reported separately; instead, they are used to enhance the interpretation and synthesis of concepts emerging from the descriptive quantitative results. The main output from such interpretation and synthesis is the analytical propositions about the innovation dynamics in developing countries.

\section{PRIORITIES OF INNOVATION FOR THE SOUTH AFRICAN TECHNOLOGY ROADMAPPING COMMUNITY}

The standard innovation value chain is divided into three key stages: idea generation, conversion, and diffusion [43]. Idea generation can be in-house, external, or through collaboration between the organisation and its partners. Conversion entails idea selection, with further development of these ideas into technology platforms, viable products, businesses, and best practices. Diffusion involves wide acceptance of these technologies, products, businesses, and best practices across the organisation, and by the targeted external recipients/market. As shown by the quantitative survey results, the main priority of innovation for TRMs developed in South Africa is technology development (70.5\% of respondents), followed at a distance by basic and/or applied research (45.5\%). It is also deduced that the likely impact of the innovation programmes that are part of South African TRMs is technological capability development $(63.6 \%)$, followed by the economic impact at country level (61.4\%), research capability development $(56.9 \%)$, and market competitiveness (54.5\%).

Therefore an inference can be drawn that South African TRMs are developed mainly for the purpose of technological capability development, followed by research capability development. Science and technology (S\&T) roadmaps have been documented extensively in the literature [44, 45]. According to Kajikawa et al. [44], S\&T roadmaps are a consensus articulation of a scientifically informed vision of attractive technology futures. On the innovation value-chain spectrum, S\&T roadmaps link idea generation with the conversion of these ideas to technologies, products, and processes.

The innovation dynamic of South African S\&T roadmaps is unique, in the sense that the focus is more on building future technological capability, starting from a weak baseline. As shown by Shin, Hong and Grupp [46], based on experience from national foresight exercises, technology planning for underdeveloped and developing countries helps to define the strategic direction for selective and indigenous S\&T development in order further to catch up economically and socially. This leads to the first proposition: 
Proposition 1: the main innovation priority for technology roadmaps in South Africa is sciencedriven technological capability development

In terms of technology roadmapping organisations, this generalisation about technological capability development applies to almost all the organisational types identified. The main issue observed is the fact that most roadmapping organisations focus more on R\&D agenda-setting as a way to develop technology platforms. The organisation types that focus mainly on R\&D agenda-setting as part of TRM development are international organisations in South Africa (100.0\% of respondents), higher education institutions $(100.0 \%)$, government $(94.4 \%)$, science councils $(88.9 \%)$, SMEs $(87.5 \%)$, NPOs $(80 \%)$, industry associations $(77.8 \%)$, international organisations outside of South Africa $(75 \%)$, and state-owned enterprises (73.3\%). The notable exceptions to this observation are large companies whose roadmaps focus more on technology platform development $(69.2 \%)$, followed by product platform development $(61.5 \%)$ and technology and market integration $(61.5 \%)$. The only technology roadmapping organisation types that seem not to prioritise technology and market integration are higher education institutions ( $25.0 \%$ of respondents) and international organisations outside of South Africa (37.5\%). Thus the following proposition is deduced:

Proposition 2: the main innovation priority for technology roadmaps of private sector companies in South Africa is technology and market integration

This analytical inference also includes state-owned enterprises; the only difference results from the fact that large companies focus more on technology platform development to respond to market needs, whereas state-owned enterprises focus more on R\&D agenda-setting as a way to integrate technology into the market. This proposition seems to be well-aligned with the main technology roadmapping literature, which defines TRMs as a strategic approach that is ideal to support the development, communication, and implementation of technology and business strategy [47]. A notable difference concerns the focus of private and public sector TRMs.

According to Londo et al. [48], whereas public sector TRMs are predominantly concerned with technology diffusion (implementation and deployment), private sector TRMs are primarily focused on R\&D and technology development. For developing countries, R\&D agenda-setting and the technology development prioritisation of the public sector serve as enablers for innovation activities in the private sector [49]. The analysis of TRM's focus per target industry also confirms the government's focus on R\&D agenda-setting (70\% of respondents) to develop technological capability. This is also the case for economic sectors that are dominated by government, such as electricity, water, and gas supply. As the mining sector is dominated by large companies, TRMs that are targeted towards this sector show the characteristics of large companies' focus areas: technology platform development (85.7\% of respondents), and technology development and market integration (85.7\%).

\subsection{Innovation competitive advantage}

Schumpeterian economic theory is premised on the assumption that innovation competitive advantage strongly depends on economic agents, such as entrepreneurs, through a process of creative destruction [50]. This section analyses the factors that influence innovation in South Africa, and the extent to which the country is embracing the opportunities that are presented by emerging technologies. In Figure 1, the main factors that influence the innovation programmes that are part of South African TRMs are arranged in terms of innovation landscape, dominant innovation regime, and niche innovations.

As Figure 1 shows, competitive advantage for innovation programmes that are part of TRMs in South Africa is aligned mainly with the R\&D capability (68.2\% of respondents), followed by a strong network of partners within the innovation ecosystem (52.3\%). As has been alluded to by various scholars, R\&D investment results in increased knowledge absorptive capacity and improved technology transfer for various organisations $[51,52,53]$.

Not all organisations perform R\&D because of the risks associated with it, such as spillover effects and technical uncertainties. Thus government typically needs to invest in R\&D at universities and other public research organisations, with the aim of stimulating innovation for the private sector mainly SMMEs. R\&D incentives are typically used to stimulate R\&D investment by large companies [54]. 
Although the respondents mentioned R\&D capability as the main innovation competitive advantage, gross R\&D expenditure in South Africa, at 0.80 per cent of GDP, is still very low compared with the Organisation of Economic Corporation and Development's average of 2.4 per cent. R\&D capability as competitive advantage is therefore in relation to other factors in the country, not necessarily in relation to the world. Another way of interpreting this stated competitive advantage is to recognise the fact that technology roadmapping organisations in South Africa, such as science councils, are highly R\&D-intensive. A main purpose of their TRMs is to convert the R\&D outputs into technology platforms, as summarised by Proposition 1.
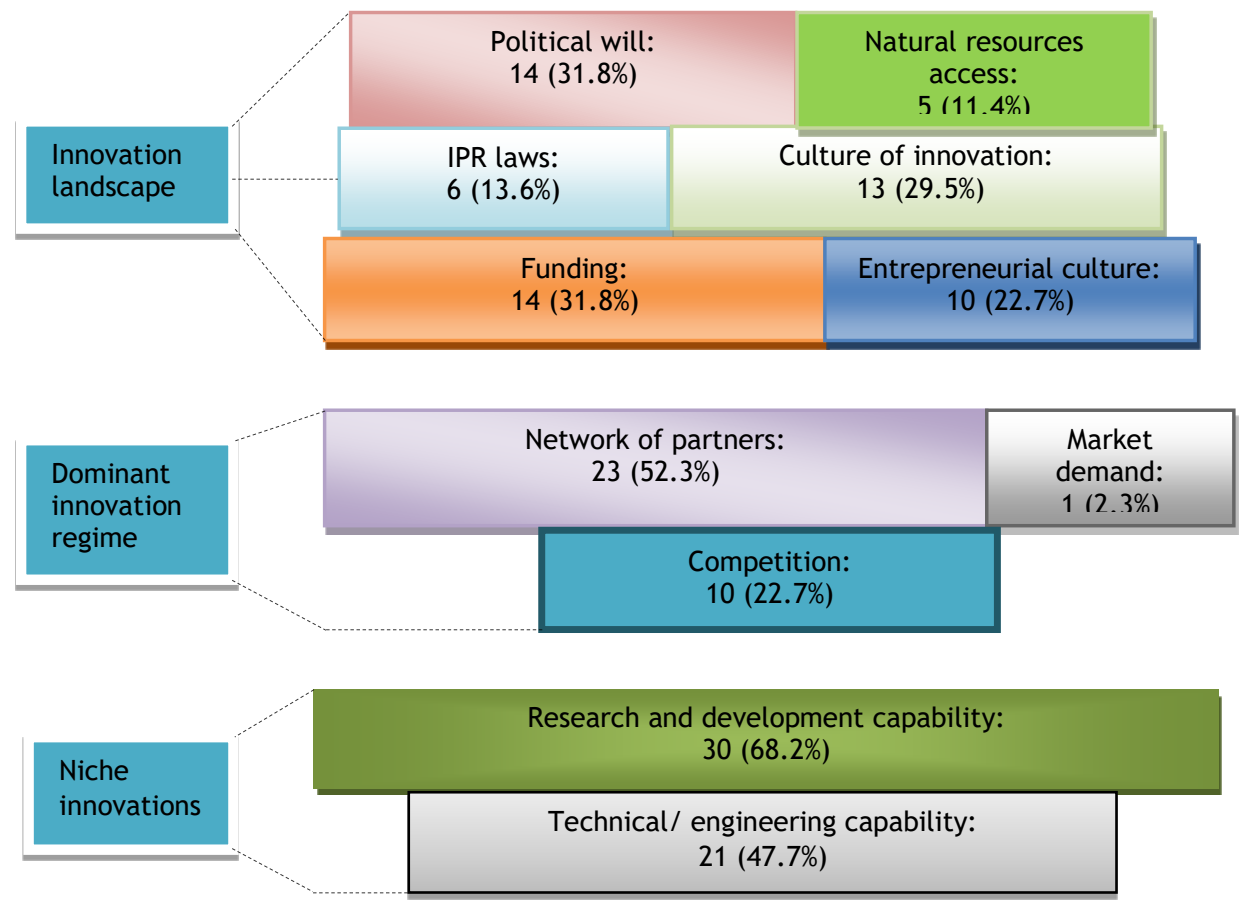

Figure 1: The main factors that positively influence the innovation programmes of TRMs

The external network of partners is important, as they can be sources of ideas [55] for knowledge creation and for technology platform development. To support this point, the National Advisory Council on Innovation (NACl) [56] has shown that South African researchers published about 84.1 per cent of scientific papers in 2013, with at least one author coming from the top 10 collaborating countries around the world. And the $\mathrm{NACl}$ [57] shows an increase in non-residents' patents registered from South Africa. As suggested by the experts, the source of these non-resident South African patents is MNCs operating in the country. Locally, R\&D collaboration between science councils and universities is strong [58]. This collaboration is also high between universities and the business sector. Thus the following proposition is deduced:

Proposition 3: external networks of partners are valuable sources of competitive advantage for innovation programmes that are part of technology roadmaps in South Africa

About 47.7 per cent considered technical or engineering capability as one of the factors that positively influence the innovation programmes that are part of South African TRMs. It is generally argued that know-how-oriented technological learning enhances firm-level competitive advantage by augmenting production efficiency [59]. As was the case with R\&D capabilities, South African engineering capabilities are still lacking, as deduced from the low proportion of high-technology exports from the country. According to $\mathrm{NACl}$ [57], South African high-technology exports, as a percentage of all merchandise exports, were only 4.01 per cent in 2015 - a slight increase from the value of 3.59 per cent during 1996.

Figure 2 shows the factors that inhibit the innovation programmes that are part of South African TRMs. Lack of funding tops the list (72.7\%), followed by lack of political will (52.3\%), and lack of entrepreneurial culture (43.2\%). The funding issue comes as no surprise, as GDP growth rates were 
1.3 per cent and 1.6 per cent during 2015 and 2014 respectively. As one of the objectives of TRMs is to commit resources to implementing the shared outlook of the technological future [60], lack of funding can have a serious impact on the ability to implement a TRM. According to detailed elaboration by some of the quantitative survey respondents, lack of political will includes issues such as policy flip-flop, as demonstrated by the initial support for renewable energy, later replaced by support for nuclear energy.
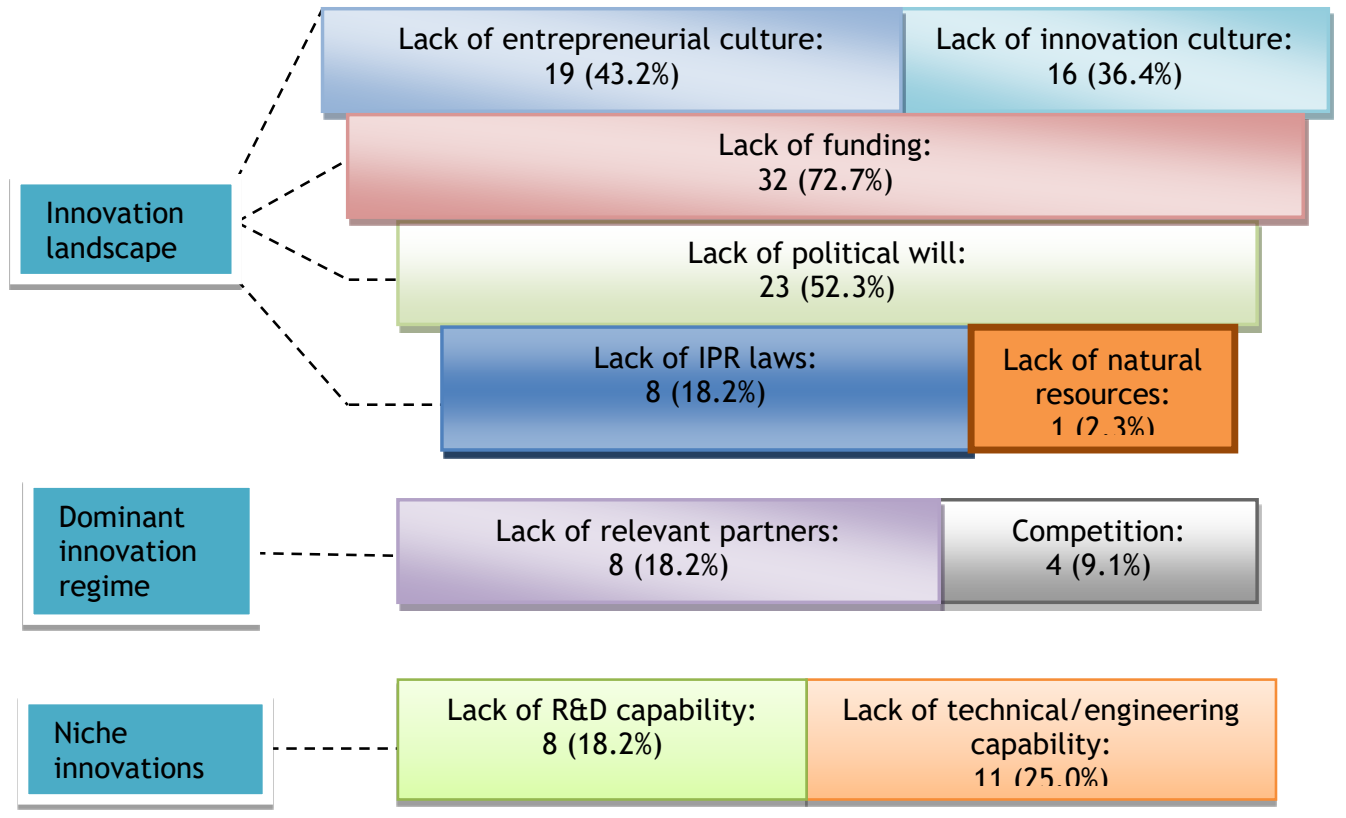

Figure 2: Main factors that negatively influence the innovation programmes of TRMs

Another dimension of the unfavourable political climate in South Africa that is mentioned is political instability and corruption. Serfontein and de Waal [61] mention the increase in reports of economic greed, retrenchments, mismanagement, inefficient government, and corruption. Both political instability or uncertainty and lack of funding are inhibitors of innovation competitive advantage that might not last in the long term. Although they need to be considered for the development of TRMs in South Africa, a window of opportunity for a positively changing innovation landscape needs to be determined to achieve TRM objectives. Political instability, lack of funding, and lack of an entrepreneurial and innovation culture are significant in a developing country's environment, such as that of South Africa. This leads to the following proposition:

Proposition 4: timing of the innovation landscape's window of opportunity is important for technology roadmapping in South Africa to create an innovation competitive advantage

According to Cooper [62], innovation success is highly dependent on the ability to accelerate product innovation, and to get products to market ahead of the competition and within the window of opportunity. Proposition 4 is therefore about converting external threats to opportunities in order to create an innovation competitive advantage that might not be obvious to the organisation's competitors. As explained by Perez and Soete [63], innovation catching-up involves being in a position to take advantage of the window of opportunity that is temporarily created by technological transitions and the shifting innovation landscape. In the technology roadmapping literature, this concept of the window of opportunity refers to seeking transition timing for the new innovation value-chain culture [64]. It has been argued that a new form of roadmapping is evolving in which roadmaps are used to persuade governments to implement actions and recommendations that are set out, or at least to facilitate their implementation [64]. Ogura [66] recommends exploring the development of a political roadmap along with a technical roadmap. As technology roadmapping organisations would not typically have a political mandate, such a political roadmap would be limited only by advocacy and persuasion strategies. 


\subsection{Opportunities presented by emerging technologies}

A recent window of opportunity is presented in the form of multiple emerging technologies through a concept known as 'the Fourth Industrial Revolution'. As shown by the results of the quantitative survey, the dominant emerging technologies that are part of TRMs in South Africa are renewable energy technologies (48.8\% of respondents), followed by the Internet of Things (IoT) or big data (37.2\%). According to Verbong and Geels [67], ongoing regime developments do not yet provide a window of opportunity for the broad uptake and diffusion of radical energy options. This is applicable to the current energy innovation landscape in South Africa, in which there is policy and political uncertainty about support for the adoption of renewable energy. The innovation landscape drivers that are more likely to open the window of opportunity for a wider adoption of renewable energy technologies are climate change shocks and shifts in public opinion [67]. Climate change mitigation target is incorporated into South Africa's future energy scenarios. According to a recently published Government Gazette [68], the four future energy scenarios that are part of the updated Integrated Resource Plan (IRP) for South Africa are: i) base case/ business-as-usual scenario, ii) resource constrained/high energy price scenario, iii) environmental awareness scenario, and iv) greenshots/high economic growth scenario. The most favourable scenarios for renewable energy niche innovators in South Africa are the 'resource constrained' and 'environmental awareness' scenarios, as they open up opportunities for renewable forms of energy to flourish. The 'greenshots' scenario also provides opportunities for renewable energy actors by virtue of high growth, although political will on issues such as the deregulation of the energy sector would play a major part in this scenario.

In terms of big data and loT, the global innovation landscape's window of opportunity opened recently through the popularisation of the Fourth Industrial Revolution concept at the 2016 World Economic Forum gathering. This industrial revolution presents opportunities for the development of smart factories [69], smart cities [70], autonomous mining, etc. The country-level innovation landscape in South Africa and other developing countries is still getting to grips with the possible impact of the Fourth Industrial Revolution, and thus there is policy uncertainty about this issue.

Most of the emerging technologies that are part of TRMs in South Africa are selected based on their alignment with global trends rather than their relevance to the country. This global trend is probably Industry 4.0. Renewable energy technologies are an exception, because they are selected based mainly on their relevance to the country ( $76.2 \%$ of respondents). With respect to socioeconomic impact, most emerging technologies are selected based on market needs (an exception in this case is environmental technologies, which are selected based on societal needs). For emerging technologies, such as aero structures, 3D/4D printing, photonics, and robotics/automation, there is a balance between selection based on R\&D and that based in engineering capabilities. R\&D and engineering capabilities are intertwined in the advanced manufacturing sector. The selection of emerging technologies based mainly on R\&D capabilities is done for biotechnology (55.6\% of respondents), environmental technologies $(50 \%)$, nanotechnology $(54.5 \%)$, and renewable energy technologies (42.9\%). The following proposition is deduced:

Proposition 5: novel innovation pathways are likely to result from technology roadmap innovation programmes that make use of biotechnology, nanotechnology, and environmental technologies.

Ground-breaking novel innovation pathways can be a great source of competitiveness and technology catch-up for developing countries. Novel nanotechnology innovations include intelligent weight management for consumers [71] and Nanobiotix technology and its role in cancer therapy [72]. These novel innovation pathways result from international market competitiveness and high profit margins [71]. The novelty of innovation pathways that make use of the three technologies mentioned in Proposition 5 are expected to impact positively mostly on new product development (NPD). Almost all the emerging technologies that are part of this study are aimed at NPD. This strong focus on NPD indicates the presence of niche innovators who seek to disrupt existing products through the emerging technologies. It is argued that innovativeness should encompass a firm's proclivity to embrace creativity, novelty, and experimentation in new product development activities [73]. In addition to the NPD, there is a balance between expected emerging technologies' impact in terms of new industry creation, improving existing products, and improvement of the current industry. 
The first two propositions address the first research sub-question with the analytical inference that the main innovation priority for TRMs in South Africa is technological capability development; and the proposal that the main innovation priority for TRMs of private sector companies in South Africa is technology and market integration. As this will also be the case for the other research subquestions, these analytical propositions are only the key issues that have been extracted: there are plenty of other relevant issues in the discussion sections. The innovation dynamic of South African S\&T roadmaps is unique, in the sense that the focus is more on building future technological capability, starting from a weak baseline.

Propositions 3 to 5 respond to the second research sub-question about the actual/perceived innovation competitive advantages for South Africa. These competitive advantages include issues such as an innovation ecosystem through an external network of partners, timing the innovation landscape's window of opportunity, and the adoption of novel innovation pathways through emerging technologies such as biotechnology, nanotechnology, and environmental technologies. Various informal and formal innovation networks have been discussed in the literature, with innovation cluster development being one such useful network. An open innovation paradigm is also useful, allowing research-intensive organisations to benefit from the complementary innovations of collaborating partners. The timing of the innovation landscape is important in a context of complex innovation systems in developing countries. Such complexity can include policy uncertainty and low technology maturity levels.

\section{REFERENCES}

[1] McDowall, W. 2012. Technology roadmaps for transition management: The case of hydrogen energy, Technological Forecasting and Social Change, 79(3), pp. 530-542.

[2] Phaal, R. \& Muller, G. 2009. An architectural framework for roadmapping: Towards visual strategy, Technological Forecasting and Social Change, 76(1), pp. 39-49.

[3] Ford, S.J., Routley, M.L.J., Phaal, R. \& Probert, D.R. 2012. Capturing past experience: The expert scan visual mapping process, International Journal of Technology Intelligence and Planning, 8(1), pp. 47-59.

[4] ASSAf. 2013. Review of the state of the science, technology and innovation system in South Africa. Pretoria: Academy of Science of South Africa.

[5] Pretorius, L. \& Benade, S.J. 2011. A systems dynamics approach to competing technologies: Exploring uncertainty of interaction and market parameters, South African Journal of Industrial Engineering, 22(2), pp. 27-39.

[6] Adner, R. 2006. Match your innovation strategy to your innovation ecosystem, Harvard Business Review, 84(4), pp. 1-11.

[7] Freitas, I.M.B., Clausen, T.H., Fontana, R. \& Verspagen, B. 2011. Formal and informal external linkages and firms' innovative strategies: A cross-country comparison, Journal of Evolutionary Economics, 21(1), pp. 91-119.

[8] Roberts, R. 1998. Managing innovation: The pursuit of competitive advantage and the design of innovation intense environments. Research Policy, 27(2), pp. 159-175.

[9] Mugabe, J.O. 2011. Science, technology and innovation in Africa's regional integration: From rhetoric to practice, ACODE Policy Research Series No. 44.

[10] Ghent Mallett, J. 2004. Silicon Valley North: The formation of the Ottawa innovation cluster, In Silicon Valley North. Emerald Group Publishing Limited, pp. 21-31.

[11] Chesbrough, H.W. \& Appleyard, M.M. 2007. Open innovation and strategy, California Management Review, 50(1), pp. 57-76.

[12] Leydesdorff, L. \& Etzkowitz, H. 1996. Emergence of a triple helix of university-industry-government relations, Science and Public Policy, 23(5), pp. 279-286.

[13] Göktepe-Hultén, D. 2008. Academic inventors and research groups: Entrepreneurial cultures at universities, Science and Public Policy, 35(9), pp. 657-667.

[14] Etzkowitz, H. \& Zhou, C. 2007. Regional innovation initiator: The entrepreneurial university in various triple helix models, in 6th International Triple Helix Conference on University, Industry and Government Linkages (TH6), 16-18 May 2007, Singapore, pp. 1-25.

[15] Lu, L. 2008. Creating knowledge-based innovation in China: The strategic implications of triple helix model, Journal of Technology Management in China, 3(3), pp. 249-263.

[16] Maassen, P. \& Stensaker, B. 2011. The knowledge triangle, European higher education policy logics and policy implications, Higher Education, 61(6), pp. 757-769.

[17] Lingela, V., Buys, A. \& Shimozawa, T. 2007. Managing factors limiting national competitiveness to improve productivity in developing countries, in Proceedings of the Portland International Conference on Management of Engineering and Technology, IEEE, pp. 2024-2030. 
[18] Bartelsman, E.J. \& Doms, M. 2000. Understanding productivity: Lessons from longitudinal microdata, Journal of Economic Literature, 38(3), pp. 569-594.

[19] Kaplinsky, R. \& Morris, M. 2001. A handbook for value-chain research. Ottawa: IDRC.

[20] Trienekens, J.H. 2011. Agricultural value-chains in developing countries: A framework for analysis, International Food and Agribusiness Management Review, 14(2), pp. 51-83.

[21] Humphrey, J. \& Schmitz, H. 2002. Developing country firms in the world economy: Governance and upgrading in global value-chains, Brighton: University of Sussex.

[22] Pietrobelli, C. \& Rabellotti, R. 2011. Global value-chains meet innovation systems: Are there learning opportunities for developing countries?, World Development, 39(7), pp. 1261-1269.

[23] Kaplinsky, R., Memedovic, O., Morris, M. \& Readman, J. 2003. The global wood furniture value-chain: What prospects for upgrading by developing countries?, UNIDO Sectoral Studies Series Working Paper, Vienna.

[24] Zamora, E.A. 2016. Value chain analysis: A brief review, Asian Journal of Innovation and Policy, 5(2), pp. 116-128.

[25] Abecassis-Moedas, C. 2006. Integrating design and retail in the clothing value chain: An empirical study of the organisation of design, International Journal of Operations and Production Management, 26(4), pp. 412-428.

[26] Gereffi, G. 2013. A global value chain perspective on industrial policy and development in emerging markets, Duke Journal of Comparative and International Law, 24, pp. 433-458.

[27] De Marchi, V., Giuliani, E. \& Rabellotti, R. 2015. Local innovation and global value chains in developing countries. UNU-MERIT Working Paper \#2015-022.

[28] Buys, A. 2013. Evidence from surveys and case studies: What we know and what we do not know about industrial innovation in South Africa, in Proceedings of Portland International Conference on Management of Engineering and Technology, pp. 732-744.

[29] Aubert, J.E. 2005. Promoting innovation in developing countries: A conceptual framework. World Bank Policy Research Research Working Paper 3554, World Bank Institute.

[30] Zhu, Y., Wittmann, X. \& Peng, M.W. 2012. Institution-based barriers to innovation in SMEs in China, Asia Pacific Journal of Management, 29(4), pp. 1131-1142.

[31] Kocoglu, I., Imamoglu, S.Z., Ince, H. \& Keskin, H. 2012. Learning, R\&D and manufacturing capabilities as determinants of technological learning: Enhancing innovation and firm performance, Procedia - Social and Behavioral Sciences, 58, pp. 842-852.

[32] Knoben, J. \& Oerlemans, L.A. 2012. Configurations of inter-organizational knowledge links: Does spatial embeddedness still matter?, Regional Studies, 46(8), pp. 1005-1021.

[33] Krishanduth, M. \& Chan, K.Y. 2012. Sustaining firm performance through cross-border knowledge transfer: The Foskor-Coromandel case study, in Proceedings of Portland International Conference on Management of Engineering and Technology, pp. 2245-2253.

[34] Stijger, R.M. \& Steyn, J.L. 2010. Contribution of support schemes to innovativeness in the South African automotive component industry, in Proceedings of Portland International Conference on Management of Engineering and Technology, pp. 1-9.

[35] Urata, S. \& Lall, S. 2003. Competitiveness, FDI and technological activity in East Asia. Washington, DC: The World Bank.

[36] Grobbelaar, S., Gauché, P. \& Brent, A. 2014. Developing a competitive concentrating solar power industry in South Africa: Current gaps and recommended next steps, Development Southern Africa, 31(3), pp. 475493.

[37] Ford, J.A., Steen, J. \& Verreynne, M.L. 2014. How environmental regulations affect innovation in the Australian oil and gas industry: Going beyond the Porter hypothesis, Journal of Cleaner Production, 84, pp. 204-213.

[38] Isaac, E. 2014. Disruptive innovation: Risk-shifting and precarity in the age of Uber, Berkeley Roundtable on the International Economy, BRIE Working Paper 2014-7.

[39] Harriss-White, B. \& Rodrigo, G. 2013. 'Pudumai'-innovation and institutional churning in India's informal economy: A report from the field, in International Symposium on Technology, Jobs and Lower Carbon Future: Methods, Substance and Ideas for the Informal Economy, New Delhi, pp. 72-113.

[40] Farrell, A.E., Redman, D.H., Corbett, J.J. \& Winebrake, J.J. 2003. Comparing air pollution from ferry and landside commuting, Transportation Research Part D: Transport and Environment, 8(5), pp. 343-360.

[41] Heckathorn, D.D. 1997. Respondent-driven sampling: A new approach to the study of hidden populations, Social Problems, 44(2), pp. 174-199.

[42] Weller, K. 2015. Social media and altmetrics: An overview of current alternative approaches to measuring scholarly impact, in Incentives and Performance. Springer International Publishing, Cham, pp. 261-276.

[43] Hansen, M.T. \& Birkinshaw, J. 2007. The innovation value chain, Harvard Business Review, 85(6), pp. 121130.

[44] Kajikawa, Y., Usui, O., Hakata, K., Yasunaga, Y. \& Matsushima, K. 2008. Structure of knowledge in the science and technology roadmaps, Technological Forecasting and Social Change, 75(1), pp. 1-11.

[45] Kostoff, R.N. \& Schaller, R.R. 2001. Science and technology roadmaps, IEEE Transactions on Engineering Management, 48(2), pp. 132-143.

[46] Shin, T., Hong, S.K. \& Grupp, H. 1999. Technology foresight activities in Korea and in countries closing the technology gap, Technological Forecasting and Social Change, 60(1), pp. 71-84. 
[47] Phaal, R., Farrukh, C.J. \& Probert, D.R. 2004. Technology roadmapping: A planning framework for evolution and revolution, Technological Forecasting and Social Change, 71(1), pp. 5-26.

[48] Londo, H.M., More, E., Phaal, R., Würtenberger, L. \& Cameron, L. n.d. Background paper on technology roadmaps (TRMs), University of Cambridge, Cambridge.

[49] El Amine, M.M. and Abderrezak, B. 2013. Micro \& macro evidence on innovation and economic performance of Algerian firms, Journal on Innovation and Sustainability, 4(1), pp. 79-100.

[50] Tüluice, N.S. \& Yurtkur, A.K. 2015. Term of strategic entrepreneurship and Schumpeter's creative destruction theory, Procedia - Social and Behavioral Sciences, 207, pp. 720-728.

[51] Berchicci, L. 2013. Towards an open R\&D system: Internal R\&D investment, external knowledge acquisition and innovative performance, Research Policy, 42(1), pp. 117-127.

[52] Schmidt, T. 2010. Absorptive capacity - one size fits all? A firm-level analysis of absorptive capacity for different kinds of knowledge, Managerial and Decision Economics, 31(1), pp. 1-18.

[53] Grünfeld, L.A. 2003. Meet me halfway but don't rush: Absorptive capacity and strategic R\&D investment revisited, International Journal of Industrial Organization, 21(8), pp. 1091-1109.

[54] Atkinson, R.D. 2007. Expanding the R\&E tax credit to drive innovation, competitiveness and prosperity, The Journal of Technology Transfer, 32(6), pp. 617-628.

[55] Chan, K.Y.A., Oerlemans, L.A. \& Pretorius, T.M. 2008. A conceptual model of the impacts of networking on innovative performance of new technology-based firms, in Portland International Conference on Management of Engineering \& Technology, pp. 443-453.

[56] NACI. 2014. South African science, technology and innovation indicators. Pretoria: National Advisory Council on Innovation.

[57] NACl. 2016. South African science, technology and innovation indicators. Pretoria: National Advisory Council on Innovation.

[58] NACl. 2015. South African science, technology and innovation indicators. Pretoria: National Advisory Council on Innovation.

[59] Bhaduri, S. \& Ray, A.S. 2004. Exporting through technological capability: Econometric evidence from India's pharmaceutical and electrical/electronics firms, Oxford Development Studies, 32(1), pp. 87-100.

[60] McDowall, W. 2012. Technology roadmaps for transition management: The case of hydrogen energy, Technological Forecasting and Social Change, 79(3), pp. 530-542.

[61] Serfontein, E. \& De Waal, E. 2015. The corruption bogey in South Africa: Is public education safe?, South African Journal of Education, 35(1), pp. 01-12.

[62] Cooper, R.G. 2001. Winning at new products: Accelerating the process from idea to launch. New York: Basic Books.

[63] Perez, C. \& Soete, L. 1988. Catching up in technology: Entry barriers and windows of opportunity, in Technical Change and Economic Theory, edited by Dosi, G. London: Pinter Publishers, pp. 458-479.

[64] Walsh, S.T. 2004. Roadmapping a disruptive technology: A case study: The emerging microsystems and top-down nanosystems industry, Technological Forecasting and Social Change, 71(1), pp. 161-185.

[65] Jeffrey, H., Sedgwick, J. \& Robinson, C. 2013. Technology roadmaps: An evaluation of their success in the renewable energy sector, Technological Forecasting and Social Change, 80(5), pp. 1015-1027.

[66] Ogura, H. 2016. Effective thermal energy utilization for automobiles, in Energy Technology Roadmaps of Japan. Springer, Tokyo, pp. 557-566.

[67] Verbong, G. \& Geels, F. 2007. The ongoing energy transition: Lessons from a socio-technical, multi-level analysis of the Dutch electricity system (1960-2004), Energy Policy, 35(2), pp. 1025-1037.

[68] DOE. 2016. Integrated energy plan. Notice 40445 of 2016, Government Gazette, Pretoria, pp. 15-226.

[69] Hermann, M., Pentek, T. \& Otto, B. 2016. Design principles for Industrie 4.0 scenarios. In 49th Hawaii International Conference on System Sciences, IEEE, pp. 3928-3937.

[70] Boulos, M.N.K., Tsouros, A.D. \& Holopainen, A. 2015. Social, innovative and smart cities are happy and resilient: Insights from the WHO EURO 2014 International Healthy Cities Conference, International Journal of Health Geographics, 14(3), pp. 1-9.

[71] Handford, C.E., Dean, M., Spence, M., Henchion, M., Elliott, C.T. \& Campbell, K. 2014. Nanotechnology in the agri-food industry on the island of Ireland: Applications, opportunities and challenges, Technical Report

[72] Num, S.M. \& Useh, N.M. 2013. Nanotechnology applications in veterinary diagnostics and therapeutics, Sokoto Journal of Veterinary Sciences, 11(2), pp. 10-14.

[73] Story, V.M., Boso, N. \& Cadogan, J.W. 2015. The form of relationship between firm-level product innovativeness and new product performance in developed and emerging markets, Journal of Product Innovation Management, 32(1), pp. 45-64. 